\title{
Organizational Work Scheme Protocols of Public Elementary School Teachers During the Covid-19 Pandemic
}

\author{
Ismael W. Baog a , MEEM, Marites L. Radin ${ }^{\mathrm{b}}$, MEEM, Wenefredo E. Cagape ${ }^{\mathrm{c}}, \mathrm{EdD}, \mathrm{PhD}$, \\ Khaskie O. Clerigo ${ }^{\mathrm{d}}$, MIT, Jamaico C. Magayo ${ }^{\mathrm{e}}$, MSciEd \\ ${ }^{\mathrm{a}}$ ismael.baog001@ deped.gov.ph/ ${ }^{\mathrm{b}}$ marites.radin001@ deped.gov.ph $/{ }^{\mathrm{c}}$ wenefredo.cagape001@ deped.gov.ph \\ ${ }^{\text {ade }}$ Currently Teaching at Davao City National High School, Davao City, 8000, Philippines \\ ${ }^{\mathrm{b}}$ Currently Teaching at San Felipe Elementary School, Davao Occidental, 8014, Philippines \\ ${ }^{c}$ Public Schools District Supervisor, Division of Davao City, Davao City, 8000, Philippines
}

\begin{abstract}
This study aimed to determine the level of organizational work scheme protocol of public school teachers in a particular district in the Division of Davao Occidental, Region XI, Philippines, during the Covid-19 Pandemic. This study utilized the descriptive design with seventy-six (76) public school elementary teachers as respondents using a cluster sampling technique. A researcher-made survey questionnaire was used to gather relevant data with the proper observance of ethical protocols. This study revealed that there is a high level of manifestation on the variables under organizational work scheme protocol such as work from home schedule, leadership support, skeletal work home arrangement, observing health protocols. Finally, the study disclosed that the organizational work scheme protocols were strictly followed by teachers in this time pandemic as it relates to facilitating healthy and successful change in their respective schools. As such, it is highly recommended that school officials from schools to the higher levels of the educational system should always manifest strong support to teachers and continue the good organizational work scheme protocols so their work attitude in the time of pandemic will be boosted. However, regular assessment must be done as part of the monitoring system and find other areas that need improvement.
\end{abstract}

Keywords: COVID-19 Pandemic; Organizational Work Scheme Protocols; Department of Education; Public Elementary School Teachers

\section{Introduction}

The challenges faced by the regular classroom teachers before the new normal educational setting are incomparable to their experiences today as they go through challenges in delivering the lessons to their learners through different learning modalities. Added to this are the different work scheme protocols that teachers should abide such as work from home arrangement, leadership support, and observing health protocols during on-site duty. Moreover, it has been observed that something is not so well in the system and the workforce. These scenarios give enough reason to determine the implementation of work scheme protocols in this challenging time, as it eventually relates to teaching performance.

Roser (2017) reported that most teachers worldwide from primary to tertiary education are experiencing challenges in the new normal teaching setup due to additional work demands, health risks in the workplace, and different work schemes. Some teachers encounter other struggles at different levels that affect their performance and effectiveness directly or indirectly (Agarao-Fernandez \& de Guzman, 2015). Moreover, there has been a deep interest in studying the organizational work scheme of employees, particularly in foreign countries. In Kenya, it was found that low work attitude among teachers in public secondary schools is caused by work-related stress (Wangui, Omboi, \& Irabo, 2016). Meanwhile, intrinsic and extrinsic motivators 
positively affect teachers' work attitudes in public secondary schools in Tanzanian Education Institution (Mruma, 2017).

In the Philippines, one identified challenge that is a primary concern by the teachers in the Department of Education during this pandemic is the work schemes. With all the sudden changes in the working scheme, teachers would still act on the main job they are called for and get the desired or expected result without jeopardizing psychological and physical health (Ancho, 2021). The Organization for Economic Cooperation and Development (2020) report shows that $62 \%$ of the teacher-respondents in the Philippines believed that the new work scheme protocols contribute to high levels of stress in teaching jobs, which would significantly decrease their work attitude. The study of Ravindran and Baral (2014) supports that organizational work schemes influence how an employee works in the organization. With better organizational work support schemes, teachers' work attitudes will improve.

With the new work scheme protocols in the education sector, teachers in Davao Region are transitioning through an uncertain period in their professional and personal lives (Allen et al., 2014). The psychological impact of the new work schemes brought by the pandemic has significant threats and dangers to a teacher's work commitment, engagement, and job satisfaction, and these are further exacerbated by the ongoing uncertainty of the situation (Oliveira, Silva, Galvao, \& Lopes, 2018). Within the new education setup, Bravo, Buenaflor, Baloloy, Guarte, Osinaga, Salartin, \& Tus, (2021) identified working environment, supportive leaders, and an excellent organizational system as factors that can help teachers be satisfied with what they are doing. Similarly, Angeles, Saludo, Virtus, and Win (2019) claimed that the management style of school administrators has a significant effect on how teachers work in school while facing challenges.

To help fill in the breach of work scheme protocols of public school teachers during the Covid-19 Pandemic, it is entirely appropriate for the researcher to pursue this issue. This study aimed to help inform stakeholders (Department Heads, Schools Heads, School Superintendent, Regional Directors, and Education Policy Makers) of the existing prevalent problems related to the organizational work scheme protocols. The results of this study will serve as a basis for recommendations and urge to revisit and ascertain the new work scheme protocols of the organization. Further, the educational planners can use the study's findings as an eyeopener to see and find a solution to the existing problem. Hence, the study's results will help administrators and heads yield frameworks and plans of actions that could revamp the better work environment of teachers.

\section{Review of Related Literature}

The coronavirus (COVID-19) pandemic continues to severely affect public health and cause unprecedented disruptions to the education sector. To contain the spread of the virus, the Department of Education has implemented the work scheme protocols; thus, the management had to adapt and make contingency plans to respond to new measures as they arise (Moralista \& Oducado, 2020). However, Oreg et al. (2011), as cited in Flovik, Knardahl, and Christensen (2019), observed that the sudden change of the organizational work scheme protocols has repeatedly been associated with adverse effects on teachers' work performance. Clarifying the impact of change in the organizational work scheme protocols for workplaces and employees is an essential first step to preventing adverse work attitude effects and facilitating a healthy and successful transition.

Due to the pandemic crisis, the change of organizational work scheme protocols in the Department of Education alters the organization's structures, strategies, procedures, or cultures (Quattrone and Hopper, 2020). The duration encompasses both the process by which this happens and the content of what is being altered. This is perhaps due to developments outside the organization's control to attain a defined goal. However, it can unintentionally have positive and negative effects, particularly when the changes in the working scheme are experienced excessively (Pellegrinelli, 2002). Prior studies have linked organizational 
work scheme protocols to employees' psycho-social aspects (Vahtera et al., 2004). Psycho-social factors include work schedules, workplace statuses such as social climate, support from superiors and co-workers, and job demands. When these factors are compromised, employee outcomes may suffer.

Work from Home Schedule. Over the years, working from home has developed into a way of working that can be used as part of an agile working program. The flexible working arrangement provides an opportunity for employees to work from home. Also, employees have the option of working from any preferred location (CIPD, 2016). This way of working allows employees to work elsewhere outside of the office environment. In the context of the COVID-19 pandemic, Brooks (2014) described "working from home" as something unique to home-based teleworking as a temporary, alternative working arrangement. It requires shared responsibility and commitment by both school management and teachers to ensure work and services continuity.

Focusing on teachers who work from home will gain further insight into whether being allowed to work from home positively or negatively influences teachers' motivation and performance levels and how this can affect work-life balance (Mann, 2013). For instance, Bick, Blandin, and Mertens (2020) found that 71.7\% of employees in the developing countries that practice work from home showed that they could not work effectively due to some reasons such as internet connection problems, household chores, care for the family members and the likes. Moreover, home working demands a quiet and dedicated space to perform work duties, which can be a real contest for those living in tiny homes. Similarly, Collins and Moschler (2009) found that employees isolated from their colleagues and supervisors are concerned about declines in productivity while working from home. Thus, for some, working from home can degrade their work attitude, which leads to low performance.

However, there is no indication of how employees who carry out different types of flexible working are more motivated, have more capacity to work or perform to a higher standard. Working from home can be beneficial for employees because it provides them with an opportunity to have a positive work-life balance (Watson \& Lightfoot, 2003). Working from home is facilitated by e-working that would improve work-life balance. Job satisfaction increases by working from home while positively associated with family-life satisfaction (Bloom, Liang, Roberts, \& Ying, 2015).

Leadership Support. Banishree Das et al. (2006), Nkhoma and Conforte (2011), Lees and Volkers (1996), and Lees (1995), as cited in Maizura and Izaidin (2014), revealed that there are issues in schools such as weak leadership, poor supervision, and mismanagement. Their findings argued that their leader causes the low work attitude of teachers and staff. As a particular purpose of the DepEd organization, schools need influential leaders to lead the operations and their employees. As reflected in the issues, it is suggested to encourage effective and good leaders in managing an institution (Kenkel \& Park, 2011 as cited in Khumalo, \& Mji, 2014).

Having a supportive school leader creates a more positive and forward-seeking climate and culture. Stress, burnout, turnover, absenteeism, and disengagement are likely to reduce while increasing the motivation to work, commitment, and job satisfaction. Poor leadership, however, has been seen as a barrier in the effects of high-demand work and low social interaction in the work environment among co-workers and supervisors (Theorell, 2015). Gutema's (2014) findings reveal that school leaders who are most effective at operation performances utilize leadership behavior and the skills and training required in educational organizations.

Leadership gives managers the ability to affect the behavior of their employees in an organization. Motivated, committed, and satisfied employees are some of the most important results of effective leadership. Thus, successful supervisors are also successful leaders because they greatly influence their employees to help accomplish organizational goals (Tsai, 2011). The achievement of educational goals is not enough to keep teachers motivated, but allowing them to achieve their personal and career goals is essential. Thus, the more 
motivated the teachers are, the more effective the leader is, and the more influential the leader is, the more motivated the teachers are.

Skeletal Workforce Arrangement. This involves reducing the number of employees who have to physically report to work and maintaining a flexible work arrangement that is critical or in the operations. Employees also reported that their organizations shifted to flexible / shortened schedules and lighter workloads (Accenture, 2020). The need for thousands of teachers to have skeletal workforce arrangements in response to COVID-19 has accelerated recent remote work trends accelerated by the rise of connectivity and communication technologies. The "remote work" is a sub-category of the skeletal workforce arrangement, which includes "work from anywhere," like home. Those jobs that need to perform complex tasks that require little interaction with peers prefer to be done and more productive from home (Allen, Cho, \& Meier, 2014).

In the case of teachers for whom collaboration and interaction among colleagues, supervisors, and students are highly needed, remote work is preferably an unconducive setting. However, several teachers are forced to follow the skeletal workforce arrangement, preferably work from home. Yet, many face challenges due to such fundamental issues as not having space in one's home to attend to work (Khumalo, 2014). Teachers who live with others also face a more extensive set of challenges than those who live alone since they also need to navigate others' space. They often find it challenging to maintain boundaries between work and non-work. An inconvenient working environment promotes a negative impact on the psychological aspect of a person, like mental health problems and anxiety (Ramarajan \& Reid, 2013).

Remote work includes: getting and staying organized, managing the delicate emotions associated with such work, figuring out and upholding an identity so that those emotions do not disturb the efficiency upon which their survival depends, coping with loneliness while also seeking out and maintaining purposeful relationships that support the work, and establishing some semblance of a longer-term (Ashford, Caza, \& Reid, 2018). The best practices, like skeletal workforce arrangement, have also been helpful for introverted employers. Such practices include actions to generate and maintain connections, actions to focus and inspire their work, explicit routines that enable work and provide boundaries between work and home, and both a place where the work is performed as well as a purpose for the work that encourages and inspires productivity as circumstances become challenging (Petriglieri, Ashford, \& Wrzesniewski, 2019).

Observing Health Protocol. The Omnibus Guidelines On The Implementation Of Community Quarantine In The Philippines with Amendments as of October 8, 2020, section 4 (11. a) stated that for primary education, the Basic Education Learning Continuity Plan of the Department of Education (DepEd) should be adopted. This includes opening classes, adopting various learning delivery options, and conducting curricular and co-curricular activities. With this, the Department of Education has released the "Guidelines on the Required Health Standards in Basic Education Offices and Schools" through DepEd Order No. 014, s. 2020, section 10, which is the "DepEd Required Health Standards" framework composed of four (4) COVID19 mitigation objectives: a) increase physical and mental resilience, b) reduce transmission, c) reduce contact, and d) reduce the duration of infection.

In order to increase the physical and mental resilience of learners, standards include re-establishment of regular and safe delivery of essential school-based services, adapted school-based feeding, continuous promotion of "school-life balance," and learners' engagement in daily physical activities provided physical distancing is observed. Also, it prioritizes the protection and promotion of the mental health and general welfare of all learners and personnel. Furthermore, it ensures appropriate support for the essential workforce, vulnerable groups, and most-at-risk population learners and personnel.

DOH AO No. 2020-0015 states that there must be the inclusion of sustaining appropriate information and education campaigns on proper handwashing and respiratory etiquette to reduce transmission in schools/CLCs and DepEd offices. Ensuring that symptomatic individuals be required to stay at home and seek medical consultation, institutionalizing routine cleaning and disinfecting of work stations at least once every 
day, providing access to basic hygiene facilities, and the rational use of personal protective equipment such as a mask are also stipulated.

To reduce contact, all schools/CLCs and offices are directed to implement strict physical distancing of at least 1 meter apart in all common areas. It limits to those most essential the travel and activities of learners and personnel. It also restricts the conduct of large physical gatherings and other activities where physical distancing may not be possible. Instead, online platforms for meetings, training, and conferences shall be utilized. Furthermore, the policy on alternative work arrangements to minimize contact in schools/CLCs and offices.

Early detection and isolation of symptomatic individuals must be ensured in all schools/CLCs and offices to reduce the duration of infection of COVID-19. The Preventive Alert System (PAS) shall continue its operation to be able to identify possible cases, and part of it is the daily health inspection to detect symptoms of infection.

According to the Department of Education, learning has to continue even with a public health emergency. To meet this need, teachers have made various efforts and strategies to sustain the education of the learners. However, it was reported that transporting learning materials has been a challenge to some teachers because often, an abrupt lockdown is declared in schools due to health-related issues of the teachers and personnel. Some locations of the schools are sometimes revealed as high-risk because of the number of COVID19 cases in the area. With this, some faculty offices are relocated, making it more difficult for the teachers to work. Maslow (1943) pointed out that for the individuals to perform their tasks efficiently and attain a fruitful outcome, their basic needs such as health, psycho-social, social security, and mental growth must be met first. When achieved, motivation among teachers will then rise towards the fulfillment of the ultimate goal of delivering quality instruction.

\section{Research Design and Methodology}

\subsection{Population/Respondents}

The respondents of this study were seventy-six (76) Public School Elementary Teachers of the nine (9) Elementary Schools from one of the school districts of Division of Davao Occidental. This study used a cluster sampling technique in choosing the teachers as respondents. The identified nine (9) schools were considered as clusters. The distribution of sampled teachers from the identified schools was summarized in Table 1. School F had provided the most significant number of teacher-respondents, while School I had the least. In total, there were 76 teacher-respondents involved in this study.

Table 1. Distribution of Respondents of the Study

\begin{tabular}{ccc}
\hline School & Total Number of Teachers & Number of Sampled Teachers \\
\hline A & 15 & 12 \\
B & 7 & 6 \\
C & 8 & 8 \\
D & 8 & 8 \\
E & 13 & 8 \\
F & 20 & 16 \\
G & 14 & 7 \\
H & 10 & 6 \\
I & 5 & 5 \\
Total & $\mathbf{1 0 0}$ & $\mathbf{7 6}$ \\
\hline
\end{tabular}




\subsection{Data Gathering Procedure}

Data collection for this study started by sending a letter of request online to the Schools Division Superintendent (SDS) of Davao Occidental Division. Once approved, the researchers submitted a letter with endorsement from the SDS to the Public Schools District Supervisor (PSDS) of Jose Abad Santos 1 District. Upon the approval of the PSDS, the researcher forwarded an endorsement letter from the PSDS to the School Heads of the identified Elementary Schools under the said district. Then, the researcher was allowed to administer the questionnaire to the teachers. Afterward, the researcher personally distributed the questionnaire to the respondents while observing the health protocol. The teachers were assured with utmost confidentiality of their responses. The respondents answered by simply putting a checkmark on the desired box that corresponds to their knowledge and experience stipulated on each item. After all the responses were retrieved, the researcher began encoding them in the Microsoft excel office application. The encoded data was then transferred to IBM SPSS 25 for statistical analysis.

\subsection{Data Gathering Instrument}

The researcher utilized a self-made questionnaire based on the functions and duties of the teachers. A Likert-type questionnaire was submitted for approval and validation by the panel of experts. The questionnaire contained twenty (20) statements about teachers' organizational work scheme protocols, with five (5) statements on each subdomain.

The survey questionnaire was sent to three (3) experts for validation. After the validity test, the survey questionnaire was piloted to twenty (20) teachers. It was then checked for reliability using Cronbach alpha. It showed that all items in Organizational Work Scheme Protocols $(0.86>0.70$ reliability index $)$ passed the required standard, thus considered as reliable.

\section{Results and Discussion}

\subsection{Work from Home Schedule}

Presented in Table 2 is the level of organizational work scheme protocols of public elementary school teachers in the Division of Davao Occidental in terms of work from home. It reveals that the statement "as teachers, we render 8-hour work for five days" obtained the highest mean value among the five (5) statements $(\overline{\mathrm{X}}=4.70, \mathrm{SD}=0.61)$, which is described as "very highly manifested." On the other hand, the statement "as teachers, we collect the different learning modality of the pupils while working at home" obtained the lowest mean value among the five (5) statements $(\overline{\mathrm{X}}=3.85, \mathrm{SD}=0.97)$ which is described as "highly manifested." It reveals further that the overall mean value on the level of organizational work scheme protocols of teachers in terms of work from home is 4.28 ( $\mathrm{SD}=0.54)$, which is described as "very highly manifested."

Table 2. Level of Organizational Work Scheme Protocols of Teachers in terms of Work from Home.

\begin{tabular}{lccc}
\hline \multicolumn{1}{c}{ Statements } & Mean & SD & Description \\
\hline As teachers... & & & \\
1. we deserve the policy on academic ease. & 4.41 & .72 & Very Highly Manifested \\
2. we establish a strategic arrangement to keep in touch & 4.19 & .65 & Highly Manifested \\
with our pupils through the different learning modalities. & & & \\
3. we closely follow the work-from-home schedule. & 4.20 & .87 & Very Highly Manifested \\
\hline
\end{tabular}




\begin{tabular}{llll}
\hline 4. we collect the different learning modalities of the & 3.85 & .97 & Highly Manifested \\
pupils while working at home. & & & \\
5. we render 8-hour work for five days. & 4.70 & .61 & Very Highly Manifested \\
Overall Mean & $\mathbf{4 . 2 8}$ & $\mathbf{. 5 4}$ & Very Highly Manifested \\
\hline
\end{tabular}

This means that the respondents always manifest rendering 8-hour work for five days. However, they often observe collecting the different learning modalities of the pupils while working at home. This implies that teachers always follow work from home protocol. This finding has confirmed the claim of According to Moralista and Oducado (2020), who argued that the Department of Education had implemented the work scheme protocols. Thus, the management must adapt and make contingency plans to respond to new measures as they arise to contain the spread of the virus. Moreover, the change of organizational work scheme protocols due to the pandemic crisis alters the organization's structures, strategies, procedures, or cultures. The duration encompasses both the process by which this happens and the content of what is being altered, perhaps due to developments outside the organization's control to attain a defined goal (Quattrone and Hopper, 2001).

Working from home has developed to work that can be used as part of the alternative working program. The flexible working arrangement provides the opportunity for employees to work from home. Also, employees have the option of working from any preferred location. This way of working allows employees to work elsewhere outside of the office environment (CIPD, 2016). Thus, Brooks (2014) pointed out that school management and teachers require shared responsibility and commitment to ensure work and services continuity. According to Watson and Lightfoot (2003), some employees who carry out these different types of flexible working conditions are more motivated; they have more capacity for work or perform to a higher standard. It can be beneficial for employees because it allows them to have a positive work-life balance.

\subsection{Leadership Support}

Presented in Table 3 is the level of organizational work scheme protocols of public elementary school teachers in the Division of Davao Occidental in terms of leadership support.

Table 3. Level of Organizational Work Scheme Protocols of Teachers in terms of Leadership Support.

\begin{tabular}{|c|c|c|c|}
\hline Statements & Mean & SD & Description \\
\hline \multicolumn{4}{|l|}{ As teachers... } \\
\hline $\begin{array}{l}\text { 1. we are always supported by my superiors in addressing } \\
\text { issues on distance learning. }\end{array}$ & 4.53 & .65 & Very Highly Manifested \\
\hline $\begin{array}{l}\text { 2. the school head provides support in handling classes } \\
\text { amidst this pandemic. }\end{array}$ & 4.26 & .99 & Very Highly Manifested \\
\hline $\begin{array}{l}\text { 3. the school formulates its instructional materials for the } \\
\text { pupils. }\end{array}$ & 4.14 & .85 & Highly Manifested \\
\hline $\begin{array}{l}\text { 4. the school conducts its monitoring of our delivery of } \\
\text { the lessons to ensure active engagement of the pupils. }\end{array}$ & 4.38 & .70 & Very Highly Manifested \\
\hline $\begin{array}{l}\text { 5. the school supports us in the full completion of their } \\
\text { assigned tasks. }\end{array}$ & 4.56 & .62 & Very Highly Manifested \\
\hline Overall Mean & 4.36 & .56 & Very Highly Manifested \\
\hline
\end{tabular}

It reveals that the statement "the school supports us in the full completion of their assigned tasks" obtained the highest mean value among the five (5) statements $(\overline{\mathrm{X}}=4.56, \mathrm{SD}=0.62)$ which is described as 
"very highly manifested." On the other hand, the statement "the school formulates its instructional materials for the pupils" obtained the lowest mean value among the five (5) statements $(\overline{\mathrm{X}}=4.14, \mathrm{SD}=0.85)$ which is described as "highly manifested." It further reveals that the overall mean value of organizational work scheme protocols in leadership support is $4.36(\mathrm{SD}=0.56)$, which is described as "very highly manifested."

This means that the respondents always manifest support from the school in the full completion of the assigned tasks. On the other hand, the respondents often manifest that their school formulates its instructional materials for the pupils. This implies that teachers always receive support from their leaders.

Similarly, Theorell, et.al (2015) posited that having a supportive school leader creates a more positive and forward-seeking climate and culture. Stress, burnout, turnover, absenteeism, and disengagement are likely to reduce while increasing the motivation to work, commitment, and job satisfaction. Poor leadership, however, has been seen as a barrier in the effects of high-demand work and low social interaction in the work environment among co-workers and supervisors. As a particular purpose of the DepEd organization, schools need influential leaders to lead the operations and their employees. As reflected in the issues, it is suggested to encourage effectiveness and good leaders managing an institution (Kenkel \& Park, 2011 as cited in Khumalo \& Mji, 2014).

\subsection{Skeletal Workforce Arrangement}

Presented in Table 4 is the level of organizational work scheme protocols of public elementary school teachers in the Division of Davao Occidental in terms of skeletal workforce arrangement.

It reveals that statement "as teachers, we follow the workforce arrangement for reporting which is set by the school" obtained the highest mean value among the five (5) statements $(\overline{\mathrm{X}}=4.56, \mathrm{SD}=0.79)$, which is described as "very highly manifested." On the other hand, the statement "as teachers, we observe skeletal workforce arrangement" obtained the lowest mean value among the five (5) statements $(\overline{\mathrm{X}}=4.38, \mathrm{SD}=0.93)$ which is described as "very highly manifested." It also reveals that the overall mean value on the level of organizational work scheme protocols of teachers in terms of skeletal workforce arrangement is 4.49 $(\mathrm{SD}=0.73)$, which is described as "very highly manifested."

Table 4. Level of Organizational Work Scheme Protocols of Teachers in terms of Skeletal Workforce Arrangement

\begin{tabular}{|c|c|c|c|}
\hline Statements & Mean & SD & Description \\
\hline \multicolumn{4}{|l|}{ As teachers... } \\
\hline 1. we observe skeletal workforce arrangement. & 4.38 & .93 & Very Highly Manifested \\
\hline $\begin{array}{l}\text { 2. we follow the workforce arrangement for reporting, } \\
\text { which the school sets. }\end{array}$ & 4.56 & .79 & Very Highly Manifested \\
\hline $\begin{array}{l}\text { 3. we can attest that the school management schedules the } \\
\text { number of teachers who will report to school every day. }\end{array}$ & 4.50 & .88 & Very Highly Manifested \\
\hline $\begin{array}{l}\text { 4. we observe that the school management directs the } \\
\text { department heads to strictly follow the number of teachers } \\
\text { who will report in each department. }\end{array}$ & 4.50 & .94 & Very Highly Manifested \\
\hline $\begin{array}{l}\text { 5. we strictly follow the order for skeletal force } \\
\text { arrangement. }\end{array}$ & 4.53 & .92 & Very Highly Manifested \\
\hline Overall Mean & 4.49 & .73 & Very Highly Manifested \\
\hline
\end{tabular}


This means that the respondents always manifest following the workforce arrangement for reporting, which the school sets. On the other hand, they always manifest observing skeletal workforce arrangement. This implies that teachers always follow skeletal workforce arrangements.

The finding supports the report of Accenture (2020) that the Department of Education has reduced the number of employees who have to report to work physically and maintain a flexible work arrangement whose functions are critical or in the operations. Teachers also said that their schools shifted to flexible / shortened schedules and lighter workloads. Such practices include actions to generate and maintain connections, actions to focus and inspire their work, explicit routines that enable work and provide boundaries between work and home, and both a place where the work is performed as well as a purpose for the work that encourages and inspires productivity as circumstances become challenging (Petriglieri, Ashford, \& Wrzesniewski, 2019).

\subsection{Observing Health Protocol}

Presented in Table 5 is the level of organizational work scheme protocols of public elementary school teachers in the Division of Davao Occidental in terms of skeletal observing health protocol.

It reveals that statement "as teachers, we always observe health protocols such as wearing of a mask, face shield, washing of hands with soap and sanitizing our hands with alcohol in coming to school" obtained the highest mean value among the five (5) statements $(\overline{\mathrm{X}}=4.78, \mathrm{SD}=0.51)$ which is described as "very highly manifested." On the other hand, the statement "the school establishes information system and booth to cater and address the needs of stakeholders during these times of pandemic" obtained the lowest mean value among the five (5) statements $(\overline{\mathrm{X}}=4.46, \mathrm{SD}=0.71)$, which is described as "very highly manifested." It further shows that the overall mean value on the level of organizational work scheme protocols of teachers in terms of observing health protocols is 4.60 ( $\mathrm{SD}=0.44)$, which is described as "very highly manifested."

Table 5. Level of Organizational Work Scheme Protocols of Teachers in terms of Observing Health Protocol

\begin{tabular}{|c|c|c|c|}
\hline Statements & Mean & SD & Description \\
\hline \multicolumn{4}{|l|}{ As teachers... } \\
\hline $\begin{array}{l}\text { 1. we always observe health protocols such as wearing a } \\
\text { mask, face shield, washing hands with soap, and }\end{array}$ & 4.78 & .51 & Very Highly Manifested \\
\hline sanitizing our hands with alcohol when coming to school. & & & \\
\hline $\begin{array}{l}\text { 2. we observe that the school implements proper protocols } \\
\text { to protect its teachers from the COVID } 19 \text { infections. }\end{array}$ & 4.75 & .49 & Very Highly Manifested \\
\hline $\begin{array}{l}\text { 3. we are part of crafting the school's health and sanitation } \\
\text { plan for the teacher. }\end{array}$ & 4.57 & .66 & Very Highly Manifested \\
\hline $\begin{array}{l}\text { 4. the school implements the monitoring of body } \\
\text { temperature for all persons who enter the school premises. }\end{array}$ & 4.53 & .65 & Very Highly Manifested \\
\hline $\begin{array}{l}\text { 5. the school establishes an information system and booth } \\
\text { to cater to and address the needs of stakeholders during } \\
\text { this time of the pandemic. }\end{array}$ & 4.46 & .71 & Very Highly Manifested \\
\hline Overall Mean & 4.60 & .44 & Very Highly Manifested \\
\hline
\end{tabular}

This means that the respondents always observe health protocols such as wearing a mask, face shield, washing hands with soap, and sanitizing our hands with alcohol in coming to school. On the other hand, they always manifest establishing information systems and booth by the school to cater to and address stakeholders' needs during these times of pandemic. This implies that teachers always observe health protocol. 
The finding corroborates the report of the Organization for Economic Cooperation and Development (2020), which narrates that the Department of Education (DepEd) adopted the Basic Education Learning Continuity Plan, which includes the opening of classes, adoption of various learning delivery options, and conduct of curricular and co-curricular activities (IATF section 4- 11. a). With this, the "Guidelines on the Required Health Standards in Basic Education Offices and Schools" through DepEd Required Health Standards framework which composed of four (4) COVID-19 mitigation objectives: a) increase physical and mental resilience, b) reduce transmission, c) reduce contact, and d) reduce the duration of infection. Learning has to continue even if there is a public health emergency. To meet this need, teachers have made various efforts and strategies to sustain the education of the learners. However, it was reported that transporting learning materials has been a challenge to some teachers because often, an abrupt lockdown is declared in schools due to health-related issues of the teachers and personnel. Some locations of the schools are sometimes revealed as high-risk because of the number of COVID19 cases in the area.

Presented in Table 6 is the summary on the level of organizational work scheme protocols of teachers in terms of work from home schedule, leadership support, skeletal workforce arrangement, and observing health protocol.

It shows that the indicator "observing health protocol" obtained the highest mean value among the four (4) indicators $(\overline{\mathrm{X}}=4.60, \mathrm{SD}=.44)$, which is described as "very highly manifested." On the other hand, the indicator "work from home schedule" obtained the lowest mean value among the four (4) indicators $(\overline{\mathrm{X}}=4.28$, $\mathrm{SD}=.54)$, which is also described as "very highly manifested." It further reveals that the overall mean of organizational work scheme protocols is $4.43(\mathrm{SD}=.41)$, described as "very highly manifested."

Table 6. Level of Organizational Work Scheme Protocols of Teachers in terms of Observing Health Protocol

\begin{tabular}{lccc}
\hline \multicolumn{1}{c}{ Statements } & Mean & SD & Description \\
\hline Work from Home Schedule & 4.28 & .54 & Very Highly Manifested \\
Leadership Support & 4.36 & .56 & Very Highly Manifested \\
Skeletal Workforce Arrangement & 4.49 & .73 & Very Highly Manifested \\
Observing Health Protocol & 4.60 & .44 & Very Highly Manifested \\
Overall Mean & $\mathbf{4 . 4 3}$ & $\mathbf{. 4 1}$ & Very Highly Manifested \\
\hline
\end{tabular}

This means that the respondents always manifest observing health protocol. On the other hand, they always manifest observing work from home schedules. This implies that teachers always follow organizational work scheme protocol. Relatedly, the study of Ravindran and Baral (2014) highlights that work attitude is influenced by organizational work schemes where an employee works; with better organizational work support schemes, teachers' work attitude was considered to improve. However, Oreg et al. (2011), as cited in Flovik, Knardahl, and Christensen (202), argued that the sudden change of the organizational work scheme protocols has repeatedly been associated with adverse effects on teachers' work performance. Clarifying the impact of change in the organizational work scheme protocols for workplaces and employees is an essential first step to preventing adverse work attitude effects of and facilitating healthy and successful change.

\section{Recommendations}

Based on the findings of this study, the following were recommended for further consideration for future studies: 
- It is highly recommended that school officials from the school to the higher levels of the educational system should continue the good organizational work scheme protocol. However, regular assessment must be done as part of the monitoring system and find other areas that need improvement.

- The Department of Education should continue to provide professional development and career opportunities to teachers while complying with the work scheme protocols in this challenging time.

- The school administrators may find this study an eye-opener about the importance of maintaining a good organizational work scheme protocol, especially in the new normal education set up to sustain the good work attitude of teachers.

- The policy-makers of the Department of Education should craft policy enforcing leaders in the Regions, Divisions, and schools to heighten their support in all means to the needs of teachers during this new normal setup.

- The policy-makers of the Department of Education should craft a policy to strengthen the programs related to teachers' health.

- Future Researchers may use this study as a reference to further investigate teachers' experiences in the new organizational work scheme protocols under the new normal education utilizing a qualitative approach.

\section{Acknowledgment}

The authors wish to acknowledge the 76 Public School Elementary Teachers of the nine 9 Elementary Schools from one of the school districts of Division of Davao Occidental for their willingness in answering the survey questionnaire. They also want to acknowledge the Schools Division Superintendent, Assistant Schools Division Superintendent, Public Schools District Supervisor of the Division of Davao Occidental for their unwavering support during the conduct of this study. The researchers are also grateful to all relatives and friends who have given their moral, financial, and physical support in one way or another. Above all, the researchers are forever thankful to the Great Almighty, the author of knowledge and wisdom, for His countless love.

\section{References}

Accenture (2020). Retrieved from: https://www.accenture.com/us-en/insights/consulting/future-work

Agarao-Fernandez, Editha \& de Guzman, Allan. (2005). Contextual Realities of Teacher Education in the Philippines. Educational Research for Policy and Practice. 4. 129-144. 10.1007/s10671-005-3360-7.

Allen, T. D., Cho, E., \& Meier, L. L. (2014). Work-family boundary dynamics. Annual Review of Organizational Psychology and Organizational Behavior, 99-121.

Ancho, I. (2021). Education Policies and COVID-19 in the Philippines: Observations and Inputs. Interdisciplinary Research Review, 16(4), 1-8. Retrieved from https://ph02.tci-thaijo.org/index.php/jtir/article/view/244018

Angeles, V., Krystelle, A., \& Tun, W.M. (2016). Job Satisfaction And Performance Level Of Employees of Ajinomoto Philippines Corporation-Lucena Branch. Retrieved from: https://pulaguna.edu.ph/wp-content/uploads/2016/08/Job-Satisfaction-AndPerformance-Level-Of-Employees-Of-Ajinomoto-Philippines-Corporation-Lucena-Branch.pdf

Ashford, S. J., Caza, B. B., \& Reid, E. M. (2018). From surviving to thriving in the gig economy: A research agenda for individuals in the new world of work. Research in Organizational Behavior, 23-41.

Bick, Alexander, Adam Blandin, and Karel Mertens (2020). "Work from Home after the Covid-19 Outbreak." CEPR Discussion Paper No. DP15000 (July).

Bloom, N., Liang, J., Roberts, J., \& Ying, Z. J. (2015). Does working from homework? Evidence from a Chinese experiment. The Quarterly Journal of Economics, 130(1), 165-218.

Bravo, Buenaflor, Baloloy, Guarte, Osinaga, Salartin, \& Tus, (2021). Amidst the COVID-19 Pandemic: The Job Burnout and Job Satisfaction of Public School Teachers in the Philippines. International Journal Of Advance Research And Innovative Ideas In Education. 7. 2021. 10.6084/m9.figshare.14832399.v1 
Brooks, C. (2014). 10 Big companies that will let you work from home. Retrieved December 15, 2020, from Yahoo: 71 https://www.yahoo.com/news/10-big-companies-let-home121235634.html

CIPD. (2016). Absence Management: Annual Survey Report. Retrieved from CIPD: https://www.cipd.co.uk/Images/absencemanagement_2016_tc m18-16360.pdf

Collins, J. H., and J. J. Moschler. 2009. "The Benefits and Limitations of Telecommuting.” Defense AR Journal 16 (1): 55-66. [Google Scholar]

Fløvik L, Knardahl S, Christensen JO., 2019. The Effect of Organizational Changes on the Psychosocial Work Environment: Changes in Psychological and Social Working Conditions Following Organizational Changes. Front Psychol. 2019 Dec 20;10:2845. DOI: 10.3389/fpsyg.2019.02845. PMID: 31920874; PMCID: PMC6932979.

Gutema, AK., (2014) The role of leadership on agricultural cooperatives performance: a case study of selected coffee farmers cooperatives in Ethiopia, University of South Africa, Pretoria, <http://hdl.handle.net/10500/18933>

Khumalo, B., \& Mji, A. (2014). Exploring Educators' Perceptions of the Impact of Poor Infrastructure on Learning and Teaching in Rural South African Schools. Mediterranean Journal of Social Sciences, 5(20), 1521. Retrieved from https://www.richtmann.org/journal/index.php/mjss/article/view/3888

Maizura, M. \& Izaidin, AM, (2014). Servant Leadership in Social Enterprise (Cooperative): They Fit!, A Review of Literature. International Journal of Business, Economics, and Law, Vol. 4, Issue 1 (June).

Mann, S. (2013). Smart Flexibility: Moving Smart and Flexible Working from Theory to Practice. Leadership \& Organisation Development Journal, 34(6), 588-589.

Maslow, A. H. (1943). A theory of human motivation. Psychological Review, 50(4), 370-396. https://doi.org/10.1037/h0054346

Moralista, M., \& Oducado, R. (2020). Faculty Perception toward Online Education in a State College in the Philippines during the Coronavirus Disease 19 (COVID-19) Pandemic. Universal Journal of Educational Research 8(10): 4736-4742, 2020. Retrieved from: https://files.eric.ed.gov/fulltext/ED608242.pdf

Mruma, S. 2017. Overview of NAFAKA Project Phase 2. Presented at the Africa RISING - NAFAKA Scaling Project End-of-project phase Review Meeting, Dar es Salaam, Tanzania, 3-4 July 2017. Morogoro, Tanzania: Tanzania Staples Value Chain Activity, NAFAKA.

Oliveira AM, Silva MT, Galvão TF, Lopes LC. (2018). The relationship between job satisfaction, burnout syndrome and depressive symptoms: An analysis of professionals in a teaching hospital in Brazil. Medicine (Baltimore). 2018 Dec;97(49):e13364. DOI: 10.1097/MD.0000000000013364. PMID: 30544404; PMCID: PMC6310545.

Organization for Economic Cooperation and Development (2020). Retrieved from: https://www.oecd.org/

Pellegrinelli, S. (2002). Shaping context. The role and challenge for programs. International Journal of Project Management, 20(3), 229233.

Petriglieri, G., Ashford, S. J., \& Wrzesniewski, A. (2019). Agony and ecstasy in the gig economy: Cultivating holding environments for precarious and personalized work identities. Administrative Science Quarterly, 124-170.

Quattrone, P., and Hopper, T. (2001). What does organizational change mean? Speculations on a taken-for-granted category. Manag. Account. Res. 12, 403-435. DOI: 10.1006/mare.2001.0176. https://doi.org/10.1006/mare.2001.0176

Ramarajan, L., \& Reid, E. (2013). Shattering the myth of separate worlds: Negotiating nonwork identities at work. Academy of Management Review, 621-644.

Ravindran, B., \& Baral, R. (2014). Factors Affecting the Work Attitudes of Indian Re-entry Women in the IT Sector. Vikalpa, 31-42.

Roser, M. (2017). "Teachers and Professors". Published online at OurWorldInData.org. Retrieved from: 'https://ourworldindata.org/teachers-and-professors'

Theorell, Töres \& Hammarström, Anne \& Aronsson, Gunnar \& Bendz, Lil \& Grape, Tom \& Hogstedt, Christer \& Marteinsdottir, Ina \& Skoog, Ingmar \& Hall, Charlotte. (2015). A systematic review including meta-analysis of work environment and depressive symptoms. BMC public health. 15. 10.1186/s12889-015-1954-4.

Tsai, Y. (2011). Relationship between Organizational Culture, Leadership Behavior, and Job Satisfaction. BMC Health Services Research, 11(98). doi:https://doi.org/10.1186/1472-6963-11-98

Tus, Jhoselle \& Garcia, Stephen \& Pascua, Princess Kim \& Felonia, Jhoana \& Quiwa, Jireh \& Cruz, Rhoyet \& Espiritu, Nicole \& Paras, Niña \& Ranis, Rhanarie. (2021). The Impact of Job Burnout on the Job Satisfaction of Filipino Adolescents in Selected Areas in Central Luzon, Philippines Amidst the COVID-19 Pandemic. 11. 55-75. 10.6084/m9.figshare.16968541.v1.

Wangui, M.F., Omboi, K., Irabo, M., Effects of WorkRelated Stress on Teachers Performance in Public Secondary Schools in Kikuyu Sub County, Kenya. International Journal of Science and Research, Volume 5, Issue 5, May 2016, 1645-1652. Retrieved from https://www.ijsr.net/archive/v5i5/20051601.pdf

Watson, I., \& Lightfoot, D. (2003). Mobile working with Connexions. Facilities, 21(13/14), 347-352.

Vahtera J, Kivimäki M, Pentti J, Linna A, Virtanen M, Virtanen P, Ferrie JE. (2004). Organizational downsizing, sickness absence, and mortality: 10-town prospective cohort study. BMJ. 2004 Mar 6;328(7439):555. DOI: 10.1136/bmj.37972.496262.0D. Epub 2004 Feb 23. PMID: 14980982; PMCID: PMC381046. 